\title{
WATER QUALITY INDICATORS IN THE MANTIQUEIRA RANGE REGION, MINAS GERAIS STATE
}

\author{
Leandro Campos Pinto ${ }^{1}$, Carlos Rogério de Mello ${ }^{1 *}$, Léo Fernandes Ávila
}

*Corresponding author: crmello@deg.ufla.br

\begin{abstract}
Maintaining the quality of water resources is of great importance for environmental preservation and the quality of life of consumers, and is one of the greatest challenges facing humanity today. Land-use for agriculture and animal farming significantly changes the biological, physical and chemical characteristics of natural systems. This study comprised monitoring of two subbasins located in the Mantiqueira Range region, from which water samples were collected on a monthly basis between June 2010 and May 2011 for analysis. Each subbasin has a distinct vegetation cover, one being predominantly covered by pastureland and the other being entirely covered by Atlantic Forest. The following water quality indicators were analyzed: turbidity, $\mathrm{pH}$, electrical conductivity, total dissolved solids, dissolved oxygen, temperature, nitrate, phosphate, BOD, COD, total and fecal coliforms, and respective discharge measurement. The results showed that water quality degradation in both environments coincided with the local rainy season and was influenced by transport of organic material to watercourses by direct surface runoff. The high concentrations of fecal coliforms found affected the water quality, particularly in the rainy season, and are associated with agriculture and animal farming, the main economic activities in the region. The Atlantic Forest environment, however, had statistically better water quality over time in relation to the pastureland environment, due to the buffering it provides to direct surface runoff.
\end{abstract}

Key words: Forest hydrology, Atlantic Forest, land use, water quality.

\section{INDICADORES DE QUALIDADE DE ÁGUA NA REGIÃo DA SERRA DA MANTIQUEIRA, MG}

RESUMO: A manutenção da qualidade dos recursos hídricos é de suma importância para a preservação ambiental e qualidade de vida dos usuários, sendo hoje, um dos grandes desafios da humanidade. O uso do solo pelas atividades agropecuárias altera sensivelmente os processos biológicos, físicos e químicos dos sistemas naturais. Neste estudo, foram monitoradas duas sub-bacias localizadas na Serra da Mantiqueira, onde foram coletadas amostras de água para análise entre junho de 2010 e maio de 2011 , com periodicidade mensal. As duas sub-bacias apresentam distintas coberturas vegetais, sendo uma predominantemente sob pastagem e outra inteiramente sob Mata Atlântica. Foram analisados os seguintes indicadores associados à qualidade de água: turbidez, $\mathrm{pH}$, condutividade elétrica, sólidos dissolvidos totais, oxigênio dissolvido, temperatura, nitrato, fosfato, DBO, DQO, coliformes totais e fecais e a vazão dos cursos d'água. Os resultados das análises mostraram que a degradação da qualidade da água em ambos os ambientes monitorados, coincidiu com o periodo chuvoso na região, influenciada pelo transporte de material orgânico aos cursos d'água, pelo escoamento superficial direto. As elevadas concentrações de coliformes fecais afetaram a qualidade dos cursos d'água, principalmente no período chuvoso e estão associadas à agropecuária, principal atividade econômica exercida na região. No entanto, o ambiente sob Mata Atlântica apresentou, estatisticamente, uma melhor qualidade de água ao longo do tempo em relação ao ambiente sob pastagem, devido à maior proteção que a mesma exerce ao escoamento superficial.

Palavras-chave: Hidrologia florestal, Mata Atlântica, uso do solo, qualidade de água.

\section{INTRODUCTION}

The Mantiqueira Range region boasts several headwaters that form important rivers in southern Minas Gerais state which in turn cater for a variety of local uses, including public water supply, irrigation and power generation, among others.

Maintaining the quality of local water resources deserves prior attention so that to ensure environmental preservation in southern Minas Gerais state for future generations. Understanding the dynamics of natural processes requires painstaking efforts and often relies on periodic monitoring over time, potentially taking years in some cases for research studies to produce conclusive results.

Pereira et al. (2010) reported that environmental modeling absolutely requires understanding the hydrologic patterns of forested areas, referring in particular to Atlantic Forest in Mantiqueira Range region, as it has been gradually replaced by extensive low-bearing capacity pasture.

Menezes et al. (2009) analyzed the hydrologic dynamics of two headwater areas with distinct vegetation covers in the Lavrinha Creek Watershed (LCW), in Mantiqueira Range region (MG), one under forest (Atlantic Forest) and the other under pasture. The authors concluded

${ }^{1}$ Universidade Federal de Lavras - Lavras, Minas Gerais, Brazil

Cerne, Lavras, v. 19, n. 4, p. 687-692, out./dez. 2013 
that land use in areas of headwater recharge influenced both the amount and the temporal dynamics of specific water flow, and also that these effects are minimized if effective maintenance of the vegetation cover is ensured, in particular under Atlantic Forest.

With that in mind, this study was aimed at monitoring the water quality of two subbasins located in Mantiqueira Range region, through monthly analysis of turbidity, $\mathrm{pH}$, electrical conductivity, total dissolved solids, dissolved oxygen, temperature, nitrate, phosphate, BOD, COD, total and fecal coliforms and respective discharge. The pattern of watercourse quality was addressed according to the vegetation cover in each subbasin, one being under pasture and the other under forest (Atlantic Forest) landuses.

\section{MATERIAL AND METHODS}

\subsection{Location and characteristics of the study sites}

The study sites are enclosed in an experimental watershed known as Lavrinha Creek Watershed (LCW), which is located in the Mantiqueira Range region, close to the municipality of Bocaina de Minas - MG (Figure 1). LCW has an area about 687 ha and an average slope of $35 \%$. The local climate, under the Thornthwaite classification, is Hyperhumid A1, which means having a positive water balance throughout the year, while under the Köppen classification the climate is Cwb type, which means having mild, rainy summers and cold, dry winters (CARVALHO et al., 2008; SPAROVEK et al., 2007). The dominant soils, according to Menezes et al. (2009), are cambisol for the most part, litholic neosol and fluvic neosol.

The pasture landscape is predominantly native and has low-bearing capacity, but nonnative pasture areas are also present. The local population is mainly engaged in animal farming and family agriculture on small land plots. According to Scolforo et al. (2008), the headwaters area of

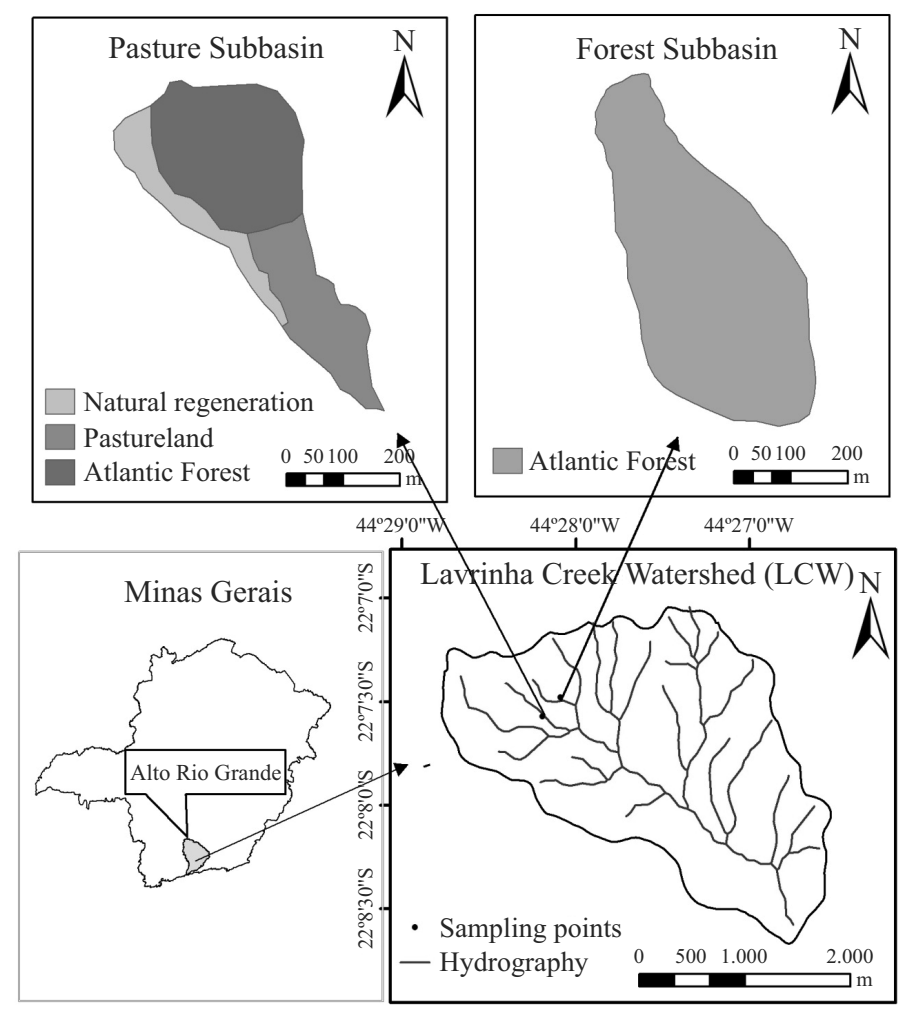

Figure 1 - Map of Minas Gerais state, with location of the Alto rio Grande basin, LCW as well as Forest and Pasture subbasins.

Figura 1 - Mapa de Minas Gerais, com identificação da Bacia do Rio Grande, Bacia Hidrográfica do Ribeirão Lavrinha e Microbacias Florestal e Pastagem.

Cerne, Lavras, v. 19, n. 4, p. 687-692, out./dez. 2013 
the Mantiqueira Range region sits in an area of seasonal semideciduous ombrophilous forest.

Figure 2 illustrates the pattern of monthly precipitation during the monitoring period, according to

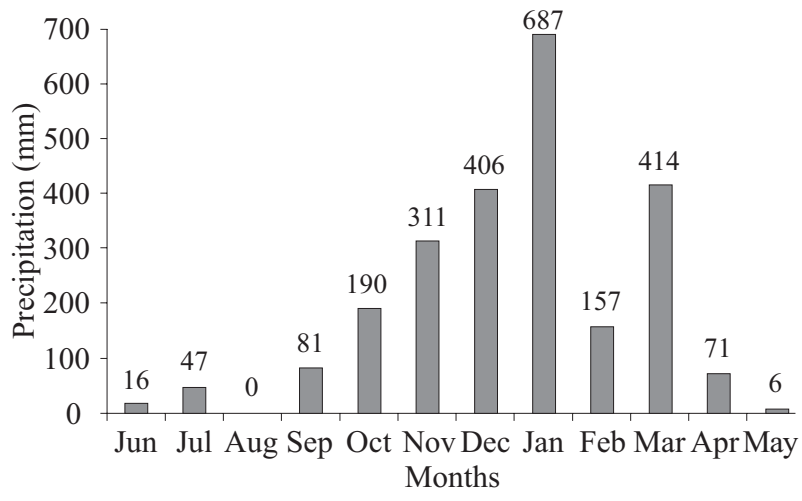

Figure 2 - Total monthly precipitation in the LCW from June 2010 to May 2011.

Figura 2 - Precipitação total mensal na Bacia Hidrográfica do Ribeirão Lavrinha durante o periodo de junho de 2010 a maio de 2011.

data sourced from an automatic weather station installed close to Forest Subbasin.

\subsection{Monitoring of surface water quality}

Hydrologic monitoring consisted of inspecting the quality of water generated in the subbasin exclusively occupied by Atlantic Forest (Forest Subbasin), and then comparing the results with data from the other subbasin, whose area is predominantly occupied by pastures despite the presence of some forest fragments in its headwaters (Figure 1). Despite the occurrence of forest fragments in the latter subbasin, it was characterized as pasture due to the predominant use in virtually the entirety of the river (Pasture Subbasin).

Samples were collected from a central point of cross sections of the relevant streams and subjected to in-situ and laboratory analysis.

In order to describe the pattern of rivers throughout various climate seasons, sampling was spaced over a oneyear period for each subbasin and covered the period from June 2010 to May 2011. Two samples were discarded due to some problems during monitoring and laboratory procedures, leaving a total of 10 samples in each study site.

Analysis of water quality indicators included turbidity (Nephelometric Turbidity Units - NTU), pH, electrical conductivity (EC), total dissolved solids (TDS), dissolved oxygen (DO), temperature (T), nitrate $\left(\mathrm{NO}_{3}\right)$ phosphate $\left(\mathrm{PO}_{4}\right)$, biochemical oxygen demand (BOD), chemical oxygen demand (COD), total coliforms (TC), fecal coliforms (FC), and monitoring of respective discharge, were conducted.

The indicators $\mathrm{pH}$, dissolved oxygen, temperature, electrical conductivity, turbidity and total dissolved solids were analyzed in the field using a Consort ${ }^{\circledR}$ C535 multiparameter analyzer and a Digimed $\AA$ DM-TU digital turbidity meter. For the 5-day BOD test at $20^{\circ} \mathrm{C}$, dissolved oxygen was measured by titration. Nitrate and phosphate were determined using spectrophotometry (bench photometer). COD was determined using spectrophotometry by the closed-tube digestion method. The most probable number (MPN) of total and fecal coliforms was determined by the multiple-tube method (AMERICAN PUBLIC HEALTH ASSOCIATION APHA, 1995).

For determination of respective discharge (Q) in the Pasture Subbasin, a Parshall flume was used with instantaneous readings, while in the Forest Subbasin an automatic gauging station was used (Figure 1).

\section{RESULTS AND DISCUSSION}

Results in Tables 1 and 2 reveal higher concentrations of BOD and COD in the Pasture Subbasin, particularly during the local rainy season (Figure 2). This pattern was due to pasture being more prone to direct surface runoff and consequently to transfer of organic material into watercourses, thus demonstrating how important the Atlantic Forest is for the binomial surface hydrology and water quality.

According to Baird (2002), BOD is indirectly the amount of biodegradable organic matter that was consumed by aerobic microorganisms present in an aquatic system, constituting an important indicator of its pollution levels. Costa et al. (2006), in an assessment of water quality in the Madureira/Lajeado Grande streams and its tributaries in Paraná state, found a significant relationship in which COD rises with increasing concentration of organic material in a watercourse.

NTU and EC values remained low (Tables 1 and 2) in both environments (forest and pasture) throughout the monitoring period, and thus did not influence watercourse quality. According to CONAMA Resolution 357/05 (CONSELHO NACIONAL DO MEIO AMBIENTE CONAMA, 2005), turbidity values less than 40 NTU relate to water conditions and quality standards required to meet

Cerne, Lavras, v. 19, n. 4, p. 687-692, out./dez. 2013 
Table 1 - Observed values for water quality indicators and respective discharge in the Forest Subbasin.

Tabela 1 - Valores observados dos indicadores de qualidade de água e da vazão na Microbacia Florestal.

\begin{tabular}{|c|c|c|c|c|c|c|c|c|c|c|c|c|c|}
\hline \multicolumn{14}{|c|}{ Forestland Subbasin } \\
\hline $\begin{array}{l}\text { Date } \\
(\mathrm{dd} / \mathrm{mm} / \mathrm{yy})\end{array}$ & NTU & $\mathrm{pH}$ & $\mathrm{EC}$ & TDS & DO & $\mathrm{T}$ & $\mathrm{NO}_{3}$ & $\mathrm{PO}_{4}$ & BOD & COD & $\mathrm{TC}$ & $\mathrm{FC}$ & Q \\
\hline $18 / 6 / 10$ & 1.3 & 5.8 & 20.3 & 10.9 & 11.0 & 16.2 & 0.2 & 0.1 & 3.0 & 5.0 & 400 & 400 & 3.6 \\
\hline $5 / 8 / 10$ & 3.3 & 6.3 & 5.0 & 11.0 & 14.1 & 14.6 & 0.1 & 0.1 & 2.5 & 3.9 & 450 & 250 & 2.7 \\
\hline $10 / 10 / 10$ & 2.9 & 6.7 & 22.5 & 12.1 & 10.7 & 15.1 & 0.0 & 0.0 & 2.6 & 1.0 & 160 & 160 & 1.6 \\
\hline $7 / 11 / 10$ & 1.8 & 6.1 & 16.4 & 8.7 & 8.5 & 16.9 & 1.4 & 0.2 & 5.5 & 8.0 & 2500 & 2500 & 1.3 \\
\hline $14 / 12 / 10$ & 3.9 & 5.9 & 10.4 & 5.6 & 7.3 & 18.4 & 0.0 & 0.1 & 5.0 & 6.0 & 750 & 450 & 8.1 \\
\hline $9 / 1 / 11$ & 2.6 & 5.2 & 8.2 & 4.5 & 6.8 & 17.5 & 0.0 & 0.0 & 4.0 & 5.0 & 1600 & 1150 & 13.6 \\
\hline $17 / 3 / 11$ & 1.3 & 6.1 & 9.6 & 5.3 & 7.8 & 17.8 & 1.6 & 0.0 & 1.0 & 3.0 & 3000 & 2500 & 7.1 \\
\hline $3 / 4 / 11$ & 4.0 & 5.3 & 12.7 & 6.7 & 9.0 & 17.5 & 0.0 & 0.0 & 1.0 & 1.0 & 400 & 400 & 3.9 \\
\hline $1 / 5 / 11$ & 3.3 & 5.4 & 13.3 & 7.2 & 11.8 & 16.0 & 0.0 & 0.0 & 1.5 & 4.0 & 6000 & 0 & 0.4 \\
\hline $29 / 5 / 11$ & 3.2 & 6.6 & 15.4 & 12.0 & 11.3 & 15.3 & 0.0 & 0.0 & 0.3 & 4.0 & 30000 & 0 & 4.0 \\
\hline Mean & 2.7 & 5.9 & 13.4 & 8.4 & 9.8 & 16.5 & 0.3 & 0.1 & 2.6 & 4.1 & 4526 & 781 & 4.6 \\
\hline
\end{tabular}

Table 2 - Observed values for water quality indicators and respective discharge in the Pasture Subbasin.

Tabela 2 - Valores observados dos indicadores de qualidade de água e da vazão na Microbacia Pastagem.

\begin{tabular}{lccccccccccccc}
\hline & & & \multicolumn{10}{c}{ Pastureland Subbasin } & \multicolumn{1}{c}{} \\
\hline $\begin{array}{l}\text { Date } \\
(\mathrm{dd} / \mathrm{mm} / \mathrm{yy})\end{array}$ & $\mathrm{NTU}$ & $\mathrm{pH}$ & $\mathrm{EC}$ & $\mathrm{TDS}$ & $\mathrm{DO}$ & $\mathrm{T}$ & $\mathrm{NO}_{3}$ & $\mathrm{PO}_{4}$ & $\mathrm{BOD}$ & $\mathrm{COD}$ & $\mathrm{TC}$ & $\mathrm{FC}$ & $\mathrm{Q}$ \\
\hline $18 / 6 / 10$ & 2.3 & 6.2 & 11.4 & 6.7 & 7.1 & 15.6 & 0.1 & 0.1 & 2.7 & 4.1 & 950 & 950 & 0.4 \\
$5 / 8 / 10$ & 2.1 & 5.6 & 6.3 & 7.9 & 13.0 & 15.2 & 0.1 & 0.1 & 3.0 & 4.2 & 930 & 0 & 0.1 \\
$10 / 10 / 10$ & 1.7 & 6.5 & 15.4 & 8.1 & 9.3 & 16.5 & 0.0 & 0.0 & 3.2 & 5.0 & 250 & 250 & 0.1 \\
$7 / 11 / 10$ & 3.9 & 6.2 & 8.1 & 4.1 & 7.4 & 21.5 & 3.3 & 0.0 & 6.0 & 9.0 & 4500 & 4500 & 0.6 \\
$14 / 12 / 10$ & 1.9 & 5.7 & 4.6 & 2.6 & 6.8 & 19.5 & 0.0 & 0.0 & 8.0 & 4.0 & 1150 & 1150 & 2.8 \\
$9 / 1 / 11$ & 2.4 & 5.1 & 5.5 & 3.0 & 6.8 & 20.1 & 0.0 & 0.0 & 6.0 & 7.0 & 2500 & 2500 & 3.2 \\
$17 / 3 / 11$ & 2.4 & 5.6 & 5.2 & 2.8 & 7.2 & 18.6 & 0.3 & 0.2 & 1.0 & 2.0 & 4500 & 1500 & 1.8 \\
$3 / 4 / 11$ & 1.7 & 5.0 & 7.2 & 3.9 & 5.4 & 18.4 & 1.8 & 0.0 & 1.0 & 3.0 & 11000 & 11000 & 0.9 \\
$1 / 5 / 11$ & 1.3 & 5.7 & 7.7 & 4.1 & 11.5 & 16.0 & 3.2 & 0.0 & 1.0 & 3.0 & 4000 & 0 & 0.6 \\
$29 / 5 / 11$ & 1.3 & 6.5 & 9.0 & 7.0 & 9.0 & 14.9 & 0.6 & 0.0 & 0.3 & 3.0 & 7000 & 0 & 0.5 \\
\hline Mean & 2.1 & 5.8 & 8.0 & 5.0 & 8.3 & 17.6 & 0.9 & 0.0 & 3.2 & 4.4 & 3678 & 2185 & 1.1 \\
\hline
\end{tabular}

preponderant use applications, current or future, while preserving the natural balance of aquatic communities. According to the environmental sanitation company Companhia de Tecnologia de Saneamento Ambiental CETESB (2008), EC levels more than $100 \mu \mathrm{S} / \mathrm{cm}$ denote impacted environments.
In both environments, $\mathrm{pH}$ remained close to 6 , though in some periods it was close to 5 in the Pasture Subbasin. These results may be an indication that land use is affecting and somehow altering water $\mathrm{pH}$ in the respective water body. Low $\mathrm{pH}$ values both in forest and in pasture environments may be related to the decomposition

Cerne, Lavras, v. 19, n. 4, p. 687-692, out./dez. 2013 
of organic matter present in the areas, releasing organic acids into the rivers. Levels os $\mathrm{pH}$ give indications of water quality (surface water between 4 and 9), of the soil type through which the water flowed, while indicating the acidity or alkalinity of the solution (MATHEUS et al., 1995).

$\mathrm{NO}_{3}$ and $\mathrm{PO}_{4}$ concentrations remained low throughout the monitoring period (Tables 1 and 2) in both Subbasins. Low values for these indicators are thought to be due to lack of fertilizer use in the study site, as pastures are native and there is no other crop ahead of the sampling points. According to CONAMA Resolution 357/05, $\mathrm{NO}_{3}$ concentrations less than $10 \mathrm{mg} / \mathrm{L}$ are not significant in terms of changing the water quality of a water body (CONAMA, 2005).

Low TDS values were found in both situations of land use (Tables 1 and 2). CONAMA Resolution 357/05 describes that TDS concentrations less than $500 \mathrm{mg} / \mathrm{L}$ are indicative of preserved environments. It should be noted, however, that where the topography of a subbasin is associated with steep slopes and low-permeability soils, TDS concentrations should be measured more frequently, since these topographic characteristics do prompt a very quick runoff response in the occurrence of precipitation (CONAMA, 2005).

According to bacteriological results, TC and FC concentrations are high in both situations of land use (Tables 1 and 2). Higher FC concentrations were found in the Pasture Subbasin, noting that the high concentrations of this indicator coincided with the months of high precipitation, in which both surface runoff and economic activity (agriculture and animal farming) contributed to the decline of water quality in the rivers. According to Merten and Minella (2002), agricultural activities can pose a great risk to the quality of water sources if the management practices adopted overlook conservation principles, that way increasing the levels of fecal coliforms.

In a study assessing water quality in the LCW, Pinto et al. (2009) found that increasing levels of heattolerant coliforms and extensive animal farming, coupled with the poor technological level adopted in such activity, were determining factors in the water quality level.

In both subbasins, lower DO concentrations were recorded during the rainy season. That denotes a strong influence of direct surface runoff, carrying organic material into the drainage system and thus affecting water quality. Table 3 reveals higher DO values in the ForestSubbasin than in the Pasture Subbasin and also that these environments differed statistically according to the F-test at 5\% probability. This pattern denotes the important role that the vegetation cover has, more specifically Atlantic Forest, in protecting watercourses, reducing the impact on water sources. According to Sperling (1996), DO is of crucial importance to aerobic organisms, as they oxidize chemical compounds to obtain the energy required for life activities. Low DO concentrations are usually indicative of excessive discharge of organic matter with high concentrations of BOD (CETESB, 2008).

Finally, it can be said that watercourse quality in the Mantiqueira range region is under the influence of the local economic activity, of the existing vegetation cover, and of the local rainfall regime, in connection with direct surface runoff. The effects of degradation on local water quality will only be alleviated through awareness of the local people as to the correct use of resources and as to the maintenance of local vegetation remnants.

Table 3-F-test applied to the indicators of water quality in both subbasins monitored.

Tabela 3 - Teste F aplicado aos indicadores de qualidade de água, em ambas as Microbacias Hidrográficas monitoradas.

\begin{tabular}{ccc}
\hline Indicator & Forestland & Pastureland \\
\hline NTU & $2.73 \mathrm{a}$ & $2.08 \mathrm{a}$ \\
pH & $5.94 \mathrm{a}$ & $5.82 \mathrm{a}$ \\
EC & $13.38 \mathrm{a}$ & $8.04 \mathrm{~b}$ \\
TDS & $8.40 \mathrm{a}$ & $5.02 \mathrm{~b}$ \\
DO & $9.81 \mathrm{a}$ & $8.34 \mathrm{~b}$ \\
T & $16.53 \mathrm{a}$ & $17.63 \mathrm{a}$ \\
NO3 & $0.33 \mathrm{a}$ & $0.94 \mathrm{a}$ \\
PO4 & $0.06 \mathrm{a}$ & $0.04 \mathrm{a}$ \\
BOD & $2.64 \mathrm{a}$ & $3.22 \mathrm{a}$ \\
COD & $4.09 \mathrm{a}$ & $4.43 \mathrm{a}$ \\
TC & $4526 \mathrm{a}$ & $3678 \mathrm{a}$ \\
FC & $781 \mathrm{a}$ & $2185 \mathrm{a}$ \\
$\mathrm{Q}$ & $4.62 \mathrm{a}$ & $1.09 \mathrm{~b}$ \\
\hline
\end{tabular}

Means followed by the same letter in a row do not differ by the F-test at $5 \%$ probability.

\section{CONCLUSIONS}

The forest environment had better water quality results than the pastureland environment, due to the greater protection it provides to watercourses.

High concentrations of fecal coliforms affected the quality of watercourses during the periods of heavier precipitation and were associated with agricultural

Cerne, Lavras, v. 19, n. 4, p. 687-692, out./dez. 2013 
activities. There was no statistically significant difference between the environments monitored regarding these parameters. DO was found to be statistically different between the two environments, with the Forest Subbasin having higher values over time.

\section{ACKNOWLEDGEMENTS}

This project received financial support from FAPEMIG PPM VI 068/12 and from CNPq (Processes 552869-2010/4 and 4716881-2009-6).

\section{REFERENCES}

AMERICAN PUBLIC HEALTH ASSOCIATION. Standard methods for the examination of water and wastewater. $19^{\text {th }}$ ed. Washington: American Water Works Association Environment Federation, 1995. 1268 p.

BAIRD, C. Química ambiental. 2. ed. Porto Alegre: Bookman, 2002.

CARVALHO, L. G.; OLIVEIRA, M. S.; ALVEAS, M. C.; VIANELLO, R. L.; SEDIYAMA, G. C.; DANTAS, A. A. A. Clima. In: SCOLFORO, J. R.; CARVALHO, L. M. T.; OLIVEIRA, A. D. (Ed.). Zoneamento ecológico econômico de Minas Gerais: componentes geofísico e biótico. Lavras: UFLA, 2008. p. 89-101.

COMPANHIA DE TECNOLOGIA DE SANEAMENTO AMBIENTAL. Variáveis de qualidade da água. São Paulo, 2008. Disponível em: <http://www.cetesb.sp.gov.br/agua/>. Acesso em: 21 abr. 2011.

CONSELHO NACIONAL DO MEIO AMBIENTE. Resolução no 357, de 17 de março de 2005. Brasília, 2005. Disponível em: $<$ http://www.mma.gov.br/port/conama/>. Acesso em: 21 jan. 2011.

COSTA, W.; MARQUES, M. B.; DELEZUK, J. A. M.; FOLKUENIG, E. S. Avaliação preliminar da qualidade da água do arroio Madureira e afluentes. Química Nova, São Paulo, v. 12, n. 1, p. 15-22, abr. 2006.

MATHEUS, C. E.; MORAES, A. J. de; TUNDISI, T. M.;

Cerne, Lavras, v. 19, n. 4, p. 687-692, out./dez. 2013
TUNDISI, J. G. Manual de análises limnológicas. São Carlos: Centro de Recursos Hídricos e Ecologia Aplicada, 1995. $62 \mathrm{p}$.

MENEZES, M. D.; JUNQUEIRA JÚNIOR, J. A.; MELLO, C. R. de; SILVA, A. M. da; CURI, N.; MARQUES, J. J. S. G. M. Dinâmica hidrológica de duas nascentes, associada ao uso do solo, características pedológicas e atributos físico-hídricos na sub-bacia hidrográfica do Ribeirão Lavrinha, Serra da Mantiqueira, MG. Scientia Forestalis, Piracicaba, v. 37, n. 82, p. 175-184, jun. 2009.

MERTEN, G. H.; MINELLA, J. P. Qualidade da água em bacias hidrográficas rurais: um desafio atual para sobrevivência futura. Agroecologia e Desenvolvimento Rural Sustentável, Porto Alegre, v. 3, n. 4, p. 33-38, out./dez. 2002.

PEREIRA, D. R.; MELLO, C. R. de; SILVA, A. M. da; YANAGI, S. N. M. Evapotranspiration and estimation of aerodynamic and stomatal conductance in a fragment of Atlantic Forest in Mantiqueira range region, MG. Cerne, Lavras, v. 16, n. 1, p. 32-40, jan./mar. 2010.

PINTO, D. B. F.; SILVA, A. M. da; MELLO, C. R. de; COELHO, G. Qualidade da água do ribeirão Lavrinha na região Alto Rio Grande, MG, Brasil. Ciência e Agrotecnologia, Lavras, v. 33, n. 4, p. 1145-1152, jul./ago. 2009.

SCOLFORO, J. R. S.; MELLO, J. M.; SILVA, C. P. Inventário florestal de Minas Gerais: floresta estacional semidecidual e ombrófila: florística, estrutura, diversidade, similaridade, distribuição diamétrica e de altura, volumetria, tendências de crescimento e áreas aptas para manejo florestal. Lavras: UFLA, 2008. 1029 p.

SPAROVEK, G.; LIER, Q. J. van; DOURADO NETO, D. Computer assisted Koeppen climate classification: on a case study for Brazil. International Journal of Climatology, Hoboken, v. 27, p. 257-266, 2007.

SPERLING, M. von. Introdução a qualidade das águas e ao tratamento de esgotos. 2. ed. Belo Horizonte: UFMG, 1996. 243 p.

Received: October 5, 2011; accepted: June 26, 2013. 